\title{
Alternatives to staff reduction in the context of labour digitalization
}

\author{
Liliya Babynina ${ }^{1, *}$, Larisa Kartashova $^{1}$, Natalia Loktyukhina ${ }^{2}$, Ekaterina Chernykh $^{3}$, and \\ Felix Akhmedov ${ }^{1}$ \\ ${ }^{1}$ Plekhanov Russian University of Economics (PRUE), Moscow, Russia \\ ${ }^{2}$ Financial Research Institute, Moscow, Russia \\ ${ }^{3}$ Federal State Budgetary Institution of Science Institute of Socio-Economic Studies of Population, \\ Russian Academy of Sciences (ISESP RAS), Moscow, Russia
}

\begin{abstract}
The article discusses alternative forms of employment in the process of staff reduction with the development of information and communication technologies in the world of work. Using the results of the research, the authors propose to critically evaluate Russian legislation in terms of the regulation of self-employment, consider new forms of employment and remote work, legislatively enshrined in the Labour Code of the Russian Federation. One of the problems highlighted in the article has related to the lack of necessary digital skills for using the Internet, which limits the possibilities of the population and employers in using alternative forms of staff reduction and interaction with employment services. Changes in the structure of the economy, the transition of personnel to remote work are accompanied by a reduction in the participation in the trade union movement, as a result, of which an employee may be forced to terminate an employment contract without social guarantees and compensation. The authors of the article argue that alternative solutions to regulate employment of the population based on the principles of social partnership and uniting the efforts of all interested parties - the state and society, representatives of employers and workers themselves.
\end{abstract}

\section{Introduction}

The digitalization of the labor market and the employment sphere changes the strategy of the behavior of the employee and the employer in connection with potential or ongoing processes of staff layoffs, which have accompanied by the de-standardization of employment. New forms of employment are emerging all over the world: telecommuting, part-time, hybrid, irregular, temporary, freelance, self-employment, work on digital labour platforms, work are using mobile or cloud applications and others. The scaling up of these forms of employment is associated with the use of information and communication technologies, which allows workers to be always in contact with employers and clients, as well as get the opportunity to represent yourself on digital labor platforms.

\footnotetext{
*Corresponding author: Babynina.LS@rea.ru
} 


\section{Materials and methods}

The authors used the results of their own research obtained within the framework of the following research projects and government assignments: "Digitalization of the labour market and employment in Russia: trends and development mechanisms", financed from the funds of the Federal State Budgetary Educational Institution of Higher Education Plekhanov Russian University of Economics" (Order No. 867 dated 28/06/2021);

"Components, social standards and indicators of the level and quality of life of the population in modern Russia: qualitative identification and quantitative assessment in conditions of socio-economic inequality" (No. 0137-2019-0032) financed from the funds of the Federal Scientific Research Center of the Russian Academy of Sciences;

"Organizational and financial mechanisms to support the employment of the population in 2021-2023, aimed at reducing the unemployment rate", carried out by the Scientific Research Institute for Basic Research under the state order of the Ministry of Finance of Russia (No. 092-00001-21-00).

Empirical methods base on the analysis of scientific foreign and Russian literature. Field research, a combination of quantitative and qualitative analysis methods, online surveys, personal and telephone interviews used to assess the challenges and opportunities for transforming the employment service of the Russian Federation to support laid-off workers and unemployed citizens.

\section{Results and discussion}

\section{1 Assessment of legislation on self-employment}

Russian studies show that in order to reduce the costs associated with the guarantees to employees provided by the Labour Code of the Russian Federation, employers can use nonstandard forms of employment that are outside the scope of labour law, which allows employees not to pay severance pay, compensation for unused vacation, etc. Employers, in violation of labour legislation, massively transfer hired workers to the category of selfemployed, concluding civil law contracts with them, or prefer to hire new employees on the terms of similar contracts. Of the 1 million self-employed registered in 2020, 400 thousand people are former employees, from whose salary fund the employer paid insurance premiums and transferred the personal income tax on the amount of $13 \%$ from the salary of each employee. The self-employed pay $4 \%$ or $6 \%$ from their income, depending on who they did the work for - for individuals or legal entities [1].

The transfer of employees to the category of self-employed frees the employer from the obligation to pay insurance premiums for the employee and guarantee the compensation provided for by the labour Code of the Russian Federation. At the same time, an employee in the status of self-employed, and in fact an employee, finds himself in a vulnerable position, deprived of guarantees and social benefits. The signs of labour relations established in Article 15 of the labour Code of the Russian Federation do not allow to unambiguously draw the line between self-employment and labour relations.

The legal status of self-employment is a subject of heated debate [2]. The position of the International labour Organization, based on the fact that "Countries should strengthen, and sometimes adapt, their social protection systems to ensure that all workers benefit from social protection coverage" [3], seems justified. A critical assessment of the Russian legislation on self-employment, which determines the legal status, rights and guarantees of this category of workers, is advisable. 


\section{2 Alternative forms of employment in case of staff reduction}

The development of non-standard forms of employment allows both the employee and the employer to implement alternative scenarios in case of staff reduction. The employee has more opportunities for part-time jobs, secondary employment, and work via the Internet. The employer, as an alternative to the dismissal of personnel, could be use a remote, parttime or temporary forms of employment [4].

The authors compiled a table of new forms of employment that as alternatives to the staff reduction in Russia (table 1).

Table 1. New forms of employment [5].

\begin{tabular}{|c|c|}
\hline Forms of employment & Content \\
\hline Interim Management & $\begin{array}{l}\text { Highly qualified specialists are temporarily engaged } \\
\text { by the company to carry out a specific project or solve } \\
\text { a specific problem or anti-crisis management. }\end{array}$ \\
\hline Job sharing & $\begin{array}{l}\text { An employer hires two or more workers to do the } \\
\text { work together (with all co-performers taking one full- } \\
\text { time job). }\end{array}$ \\
\hline Casual work & $\begin{array}{l}\text { Casual work refers to a type of work where } \\
\text { employment } \\
\text { is neither stable nor continuous. }\end{array}$ \\
\hline \multirow[t]{2}{*}{$\begin{array}{l}\text { Two main types of casual } \\
\text { work }\end{array}$} & $\begin{array}{l}\text { Intermittent work. An employers approach workers on } \\
\text { a regular or irregular basis to conduct a specific task, } \\
\text { often related to an individual project or seasonally } \\
\text { occurring jobs. }\end{array}$ \\
\hline & $\begin{array}{l}\text { On-call work. An employer does not guarantee regular } \\
\text { employment, but calls the employee on demand / } \\
\text { demand. }\end{array}$ \\
\hline ICT-based mobile work & $\begin{array}{l}\text { An employees do their work from any location, at any } \\
\text { time, with the support of modern technologies and } \\
\text { remote access to the computer systems of the } \\
\text { employer. }\end{array}$ \\
\hline Voucher-based work & $\begin{array}{l}\text { The employer pays the worker by means of vouchers } \\
\text { purchased from an authorized organization (generally } \\
\text { a governmental authority) which cover wages and } \\
\text { contributions to the social insurance system. }\end{array}$ \\
\hline Portfolio work & $\begin{array}{l}\text { The self-employed and freelancers works for many } \\
\text { clients, performing small tasks for each. The portfolio } \\
\text { of the candidate with the results of his work plays an } \\
\text { important role. It is used in some areas, for example, } \\
\text { in the creative field and the scientific and technical } \\
\text { field. }\end{array}$ \\
\hline Platform work & $\begin{array}{l}\text { Employers and workers, service providers and } \\
\text { consumers of services communicate with each other } \\
\text { through an online platform, with large tasks usually } \\
\text { spread across the workers' virtual cloud. }\end{array}$ \\
\hline $\begin{array}{l}\text { Collaborative self- } \\
\text { employment }\end{array}$ & $\begin{array}{l}\text { Freelancers, self-employed, micro-enterprises have } \\
\text { cooperate to fulfill the minimum size criteria for } \\
\text { enterprises-applicants, or to overcome the professional } \\
\text { isolation (co-working, a cooperatives) }\end{array}$ \\
\hline Outstaffing & $\begin{array}{l}\text { Removal of employees from the staff of the actual } \\
\text { employer and their transfer to the staff of the } \\
\text { employer-supplier, which are private employment } \\
\text { agencies or recruitment agencies. }\end{array}$ \\
\hline
\end{tabular}

However, the use of such forms of employment is associated with the risks of not being in demand in the labour market and loss of income for employees, especially among older people. Psychological stress is growing, many workers experience constant stress and social insecurity with the increase of precarious work. 


\section{3 Remote work}

According to the Eurostat data, the share of teleworkers only for the period from 2008 to 2019 increased from $12.4 \%$ to $16.1 \%$ [6]. In the long term, remote work will become an increasingly common alternative to staff cuts. ILO experts estimate the potential of remote work in $18 \%$ of jobs (from $12-13 \%$ in low-income countries to $25 \%$ in developed countries), which is about six times more than the proportion of those who worked remotely before the pandemic [7].

In Russia, the conditions to create for the development of this form of employment - the labour Code of the Russian Federation regulates the features of remote work, including a hybrid form, which implies combining work at home and in the office. The transfer of workers to remote work as an alternative to the dismissal is suitable for some companies, since it has a limited character and more focused on office personnel [8].

With all the advantages of remote work as an alternative to the reduction of staff, questions remain about the organization of remote work at the company level. Companies and employees need to responsibly approach the remote work format and conduct trainings and courses on managing and organizing work remotely (time management, communication skills, stress management skills when working with large flows of information) in order to increase work efficiency, exercise control, create a comfortable environment for the interaction of colleagues, promote corporate culture and minimize the level of stress [9].

\section{4 Digital Skills Assessment}

The researches by foreign authors have shown that employers searching for workers in more concentrated labour markets, demand higher the cognitive, social, and organizational skills. They write that upskilling is more prevalent among low-skill workers than high-skill ones and these workers are also more vulnerable to employment instability and low wage growth [10].

As shown of our researches, in the context of the digitalization of the economy, those who do not have the necessary digital skills prevail among the dismissed workers. Mastering digital technologies allows you to increase the competitiveness of personnel, maintain social status, but they require personal motivation, as well as accessibility to the digital environment.

According to statistics, in $2019,77 \%$ of the surveyed households had access to the Internet, which is lower than in the member states of the European Union, with the exception of Bulgaria, where this figure is $75 \%$. In $2019,72.6 \%$ of households in the Russian Federation used the Internet on a daily basis. At the same time, statistics indicate that the non-use of the Internet in households (as a percentage of the number of households without access to the Internet) occurs for the following reasons: the lack of need to use the Internet, unwillingness to use it or lack of interest in it (in $2015-66.3 \%$; in $2019-70.7 \%$ ); insufficient skills to work on the Internet (16.8\% in 2015 ; up to $32.5 \%$ in 2019; lack of sufficient financial resources to connect to the Internet $(18.6 \%$ in 2015 ; $20.8 \%$ in 2019). Only $7.3 \%$ of respondents indicated the lack of technical capabilities to connect to the Internet in 2019 [11]. Therefore, professional retraining programs are important, which will allow to maintain the activity of labor resources in situation of their limited supply and the search for talents [12]. 


\section{5 Transfer to online services of the employment service}

New strategies for employers and employees, and alternatives to dismissed employees are accompanied by an accelerated transfer to online services of the employment service. For the employer and for the employee, this means a more convenient format of online interaction on the Job in Russia portal; applying for vocational training in the framework of programs to reduce tensions in the labour market; and etc.

However, the analysis of the functioning of the Internet portal revealed a number of problems: the results of the level of user satisfaction with its work are not published; the probability of failures in its work remains; employers see a restriction of their right to choose the form of interaction with the employment service; the population lacks Internet skills.

\section{6 The role of the social partnership}

According to the research results, we revealed a tendency of the reduction of the role of social partnership in regulating labour and employment issues, which makes it possible for the employer to feel "more comfortable" when releasing personnel, and puts the employee in a vulnerable position. Changes in the structure of the economy, the transfer of personnel to "remote employment" and robotization are accompanied by a reduction in the scale of the trade union movement. In such conditions and in the absence of a trade union, an unscrupulous employer, when dismissing employees, can compel the employee to terminate the employment contract "by agreement of the parties" and thereby avoid all compensations required. Digital technologies, while creating new employment opportunities, simultaneously reinforce the challenges of protecting and representing workers' rights in the digital economy. In order to respond to the challenges of digitalization, the Russian trade union movement needs new organizational forms that go beyond specific organizations; the use of online technologies and online collective forms of action for the mass of workers.

\section{Conclusion}

In the context of the digitalization of the employment sector, the problem of staff reduction remains inevitable. In this regard, the behaviour strategy of the employee and the employer is changing, since the employer has opportunities for alternative ways of the staff reduction and providing them with a new job with the necessary digital skills. At the same time, the worker becomes more vulnerable in social and labour relations, since the de-standardization of employment is often implemented outside the legal framework. In this regard, through legal regulation, it is necessary to use the positive possibilities of the digital transformation of the world of work and ensure the protection of the rights and interests of the employee, as well as maintaining a high level of his quality of working life. The use of non-standard forms of employment, is associated with overcoming new challenges in terms of finding optimal management solutions, and will require new forms and approaches to balancing between a set of preventive employment policy measures and the choice of means of providing maximum support to those who have already lost their jobs, including financial and other incentives to increase their professional and geographic mobility. It is necessary to master digital skills that will increase the competitiveness of personnel, maintain social status, and be able to access the digital environment, including in interaction with employment services and trade unions. 


\section{References}

1. Labour relations with workers in vulnerable forms of employment must be recognized, https://www.kiout.ru/

2. W. Däubler, J. of the Higher School of Economics (2016)

3. Non-Standard Employment Around the World: Understanding Challenges, Shaping Prospects (2016)

4. M. Charalampous, C. A. Grant, C. Tramontano, E. Michailidis, European J. of Work and Organizational Psychology, 28(1) (2018)

5. Eurofound, Overview of new forms of employment - 2018 update (Publications Office of the European Union, Luxembourg, 2018)

6. Eurostat, https://ec.europa.eu/

7. Working from home: Estimating the worldwide potential, https://voxeu.org/

8. 08.12 .2020 No. 407-FZ

9. N. V. Loktyukhina, E. A. Chernykh, Living standards of the population of Russian regions, 17(1) (2021)

10. B. Hershbein, C. Macaluso, "Labor Market Concentration and the Demand for Skills", IDSC of IZA Workshop: Matching Workers and Jobs Online (Bonn, 2018)

11. Information Society in the Russian Federation 2020. Statistical Collection (Nat. issled. University Higher School of Economics, SRU HSE, 2020)

12. L. S. Babynina, L.V., Kartashova, P. P. Pilipenko, Lecture Notes in Networks and Systems (2021) 